Plant Tissue Cult. \& Biotech. 25(1): 71-85, 2015 (June)

$\overline{\text { PTC\&B }}$

\title{
In vitro Functional Analysis of Synthetic Cupep-1 and Cupep-2 Peptides from Phloem Sap of Chinese Long Cucumber
}

\author{
Hattem M. El-Shabrawi*, Mohsen Asker ${ }^{1}$, Usama I. Aly, Hassan \\ Ghareeb, Ahmed M. M. Gabr, Moemen S. Hanafy and Chun \\ Ming Liu ${ }^{2}$
}

Plant Biotechnology Department, Genetic Engineering and Biotechnology, National Research Center, Dokki, 12622 Cairo, Egypt

Key words: Phloem sap, Synthetic peptide, Antimicrobial peptide, Developmental peptide, In vitro bioassay

\begin{abstract}
The vascular system of plants consists fundamentally of two functional cell types, phloem and xylem. Phloem forms an extensive conduit for the dynamic long-distance transport of a diverse range of macromolecular signals that are required for plant development and defense mechanisms. Vascular tissues contain low levels of signaling peptide molecules, which are technically difficult to identify and characterize. We identified low molecular weight peptides from the phloem sap of Chinese Long cucumber using nano-LC-ESI-MS/MS with high SEQUEST scores. Bioinformatics analyses predicted their biological functions as signaling peptides and/or antimicrobial peptides. Here, we selected two peptides (Cupep-1 and Cupep-2), with highly SEQUEST score, to be synthesized and functionally investigated. Cupep-1 synthetic peptide showed a robust antimicrobial activity against Escherichia coli, Pseudomonas aeruginosa, Staphylococcus aureus, Bacillus subtilis and Candida albicans. These results potentiate the use of Cupep-1 peptide as a natural food preservative. We also show that the Cupep-2 peptide was able to conditionally change plant cell differentiation. Thus we suggest a role of Cupep-2 in plant development.
\end{abstract}

*Author for correspondence: <helshabrawi73@yahoo.com>. ${ }^{1}$ Microbial Biotechnology Department, Genetic Engineering and Biotechnology, National Research Center, 12311 Cairo, Egypt. ${ }^{2}$ Key Laboratory of Plant Molecular Physiology, Institute of Botany, Chinese Academy of Sciences, Beijing 100093, China. 


\section{Introduction}

In the vascular plants phloem is one of the primarily specialized tissues for translocation and distribution of organic metabolites produced during photosynthesis specially sieve elements which translocation wide range of organic metabolites (Stewart and Young 1984). In last decade researchers discovered the most important role of phloem and sieve elements in distribution of macro molecules like phytohormones, proteins and RNAs (Baker 2000, Jorgensen 2002). The expectance of macromolecules like protein and RNA in phloem was not expected because of the disability of sieve element to synthesize its Owen mRNA and proteins. Even though, the plant vascular scientist provides a strong evidence for the presenting of large number of RNAs and soluble protein in exudes substance of sieve element and companion cells which the protein synthesis are accrued (Lucas et al. 2001, Walz et al. 2004, Lough 2006). However, there are many phloem sap proteins or peptides have been discovered with specific roles in stress, defense and signal transduction (Kehr 2006). So, every living cell could have its Owen system to peptide synthesis, secretion, and posttranslational modification. These peptides are commonly used as signal molecules for intercellular communication in prokaryotes, fungi, animals and plant (Schaller 2001). Research in recent years, however, showed that peptides may also be widely used as chemical signals in plants. Moreover, plants do not only perceive endogenous peptide signals, but also react specifically to a large number of exogenous peptides produced by pathogenic microorganisms. Antimicrobial peptides (APMs) are widely attracted as a candidates for plant protection research in the past decades (Montesinos 2007). More than 900 AMPs have been identified and classified according to their structures (1) linear peptides often adopting helical structures, (2) cysteine-rich open-ended peptides containing disulphide bridges, and (3) cyclopeptides forming a peptide ring. Linear and cyclic peptides may have linked fatty acid chains (lipopeptides) or other chemical substitutions, resulting in complex molecules (pseudo peptides) (Ramadan and Asker 2012). In nature, there are a large numbers of antimicrobial compounds that play an important role in the natural defense of all kinds of living organisms (Ramadan and Asker 2009). Food-borne illness caused by consumption of contaminated foods with pathogenic bacteria has been of great concern to public health. Controlling pathogenic microorganisms would reduce food-borne outbreaks and assure consumers a continuing safe, wholesome and nutritious food supply (Allahghadri et al. 2010). To determine antimicrobial activity of the Cupep-1, the peptide was tested against selected number of microorganisms that belong to different categories, Gram-negative and positive bacteria, yeast and fungi. This was assumed to be sufficient for the antimicrobial 
screening. In this work, we investigated the in vitro biological activities of two different synthetic peptides, Cupep-1 and Cupep-2, selected from the extracted low molecular proteins of Chinese Long cucumber phloem sap and sequenced via LC/MS/MS using Chinese long cucumber data base. Then according to thier predicted functions, we piked up those two peptide sequences to be synthesized based on their prediction roles in defense and development.

\section{Materials and Methods}

The proteome sequence of (Cucumis sativus, Chinese Long) was provided by Dr. Sanwen Huang, Beijing Genome Institute (BGI)-Shenzhen, Chinese Academy of Science, Shenzhen, China.

The peptides Cupep-1 and Cupep-2 were chosen according to their predicted function as antimicrobial and developmental peptides. To those fuctions we were synthesized Their proten sequences by GenWay Biotech, Inc. (San Diego CA, USA) with automated Solid Phase Peptide Synthesis (Tsuchiya et al. 1996). They were analyzed by reverse-phase high performance chromatography and MALDITOF mass spectrometry, which revealed higher than $85 \%$ purity.

The predictions of secondary structure (Garnier et al. 1987), hydropathicity (Hopp and Woods 1981), antigenic index (Jameson and Wolf 1988), and surface probability were determined with the SEQUEST (Thermo Scientific, USA), ExPASY (http://www.expasy.org/tools/), and ProtParam servers (http://web. expasy.org/protparam/). All other predictions were made by using online services (PSORT (http://psort.hgc.jp/), signal IP 4.1 (http://www.cbs.dtu.dk/ services/SignalP/) and MotifScan (http://myhits.isb-sib.ch/cgi-bin/motif_scan). Protein sequence alignments were performed with the Protein BLAST program (http://blast.ncbi.nlm.nih.gov/). The synthesized peptide Cupep-1 was diluted in deionized water to obtain a stock solution of $5 \mathrm{mg} / \mathrm{ml}$ as the final concentration for antimicrobial activity, while Cupep-2 was diluted in phosphate buffer $(\mathrm{pH}$ 7.0) to obtain a stock solution of $25 \mathrm{nM} / \mathrm{ml}$ for plant growth activity.

Antimicrobial activity: Antimicrobial activity assays were carried out with conventional disk diffusion tests (Greenwood 1983) using cultures of Bacillus subtilis NRRL B-94, Escherichia coli NRRL B-3703, Pseudomonas aeruginosa NRRL, Staphylococcus aureus NRRL, Aspergillus niger NRRL313, Saccharomyces cervisiae NRC and Candida albicans NRRL477. The bacterial strains were cultured in nutrient medium, while Aspergillus spp.and the two yeast strains were cultured on malt- and yeast medium, respectively. Broth media included the same contents except for agar. Bacteria and yeast were incubated for $24 \mathrm{hrs}$ and Aspergillus spp. for approximately $48 \mathrm{~h}$. The growth cultures of fungus were filtered by a thin layer of sterile sintered Glass G2 to remove mycelial fragments 
before the solution containing the spores was used for inoculation. For preparation of inoculated plates, $0.5 \mathrm{ml}$ of inoculant was added to $50 \mathrm{ml}$ of agar media $\left(50^{\circ} \mathrm{C}\right)$ and mixed by simple inversion. The media was poured into $12 \mathrm{~cm}$ dia Petri dishes and allowed to cool to room temperature. Sterile filter paper disks ( $2 \mathrm{~mm}$ in dia) were saturated with peptide solution $(5,10,20,30,40,50$ and $60 \mu \mathrm{g} / \mathrm{ml})$. Three saturated filter papers were fixed on the surface of the medium for each plate. The microbial growth inhibition zone was measured after incubation at $30^{\circ} \mathrm{C}$ for $24 \mathrm{hrs}$ for yeast, $24-48 \mathrm{hrs}$ for bacteria and $48-72 \mathrm{hrs}$ for $A$. niger. The microbial inhibition zone was calculated as the mean of three replicates.

The culture medium $(50 \mathrm{ml})$ was poured into Petri dishes $(12 \mathrm{~cm} \mathrm{dia})$ and maintained at $45^{\circ} \mathrm{C}$. The synthetic Cupep- 1 peptide was added to the medium as $5,10,15,20,30,40,50$ and $60 \mu \mathrm{g} / 25 \mathrm{ml}$, while constantly stirring to ensure a uniform distribution. From the suspension of different microbial strains, $30 \mu \mathrm{l}$ were placed on the surface of the solidified culture medium containing Cupep-1. After the microorganism suspensions were absorbed into the medium, the plates were incubated at $30^{\circ} \mathrm{C}$ for $24-48 \mathrm{hrs}$. MIC was determined as the lowest concentration of Cupep-1 peptide inhibiting the visible growth of each organism on the agar plate. The microbial growth was monitored visually, and the MIC was determined according to Raaijmakers et al. (2006).

In order to investigate which molecules or processes Cupep-1 might target in order to be antimicrobially active, we tested 3.75 and $7.5 \mu \mathrm{g} / 100 \mathrm{ml}$, respectively, of the peptide on the biosynthesis of acid soluble phosphorus compounds, total lipids, proteins and nucleic acids (DNA and RNA) in the cells of B. subtilis. Immediately after inoculating flasks with $B$. subtilis, the peptide was applied in concentrations of 3.75 and $7.5 \mu \mathrm{g} / 100 \mathrm{ml}$ media. Each experiment was repeated three times. Subsequently, the flasks were shaken $(150 \mathrm{rpm})$ using a rotary shaker at $30^{\circ} \mathrm{C}$. Samples were collected at 0, 20, 40, 60, 80, 100 and 120 min after incubation. The B. subtilis were subjected to the following tests: total acid soluble phosphorus, total lipids, total soluble proteins and total nucleic acids (RNA and DNA).

The bacterial cells were collected by centrifugation at $5000 \mathrm{rpm}$, washed twice with ice cold saline and subjected to two successive extractions with $5 \%$ ice cold trichloroacetic acid (TCA). The suspensions were centrifuged at $5000 \mathrm{rpm}$. One $\mathrm{ml}$ of the extract was added to $4 \mathrm{ml}$ reagent $\left(40 \mathrm{ml}\right.$ of $6 \mathrm{~N} \mathrm{H}_{2} \mathrm{SO}_{4}, 80 \mathrm{ml}$ distilled water, $40 \mathrm{ml}$ ammonium molybdate solution and $40 \mathrm{ml}$ ascorbic acid), mixed and incubated at $37^{\circ} \mathrm{C}$ for $2 \mathrm{hrs}$ and then cooled at room temperature. The absorbance (OD) was measured at $680 \mathrm{~nm}$ (Greenwood 1983). 
The debris cells of $B$. subtilis were subjected to three successive extractions with a mixture of chloroform-methanol $(2: 1, \mathrm{v} / \mathrm{v})$. A volume of $0.1 \mathrm{ml}$ of extract was added to $5 \mathrm{ml}$ of concentrated $\mathrm{H}_{2} \mathrm{SO}_{4}$. The mixture was heated for $10 \mathrm{~min}$ in a boiling water bath and cooled, and $0.4 \mathrm{ml}$ aliquot was placed in a test tube. Six milliliters of phosphor-vanillin reagent $(0.6 \mathrm{gm}$ vanillin dissolved in $10 \mathrm{ml}$ ethanol before diluting to $100 \mathrm{ml}$ with distilled water and mixing with $400 \mathrm{ml}$ of concentrated orthophosphoric acid) was then added to each test tube. The mixture was set in the dark for $45 \mathrm{~min}$, and the absorbance (OD) was measured at $525 \mathrm{~nm}$ (Bligh and Dyer 1959, Knight et al. 1972).

The debris cells of $B$. subtilis were solubilized in $1 \mathrm{~N} \mathrm{KOH}$ at $37^{\circ} \mathrm{C}$ for $20 \mathrm{hrs}$. The total protein in the extract was determined at $595 \mathrm{~nm}$ (Bradford 1976).

The remaining portions of the sample after hydrolysis by $1 \mathrm{~N} \mathrm{KOH}$ were subjected to extraction of RNA fractions. To each sample, $6 \mathrm{~N} \mathrm{HCl}$ was added, and then the solution was completed with the same volume of $10 \%$ TCA. After adjusting the concentration, the residue was washed with 5\% TCA. One $\mathrm{ml}$ of RNA fraction was added to $3 \mathrm{ml}$ of reagent (135 $\mathrm{mg}$ of ferric ammonium sulfate and $0.2 \mathrm{~g}$ orcinol dissolved in $15 \mathrm{ml}$ distilled water, to which $85 \mathrm{ml}$ of concentrated $\mathrm{HCl}$ were added), mixed and heated for $20 \mathrm{~min}$ in a boiling water bath. The tubes were cooled at room temperature and measured at $670 \mathrm{~nm}$ (Burton 1957, Montesinos 2007).

The residue after extraction of RNA was hydrolyzed by $5 \%$ TCA, and the supernatants were heated at $90^{\circ} \mathrm{C}$ for $30 \mathrm{~min}$, cooled and centrifuged at 6,000 $\mathrm{rpm}$. The residue was washed once with 5\% TCA. One ml of DNA extract was added to $2.5 \mathrm{ml}$ of the diphenylamine reagent $(1 \mathrm{~g}$ of diphenylamine dissolved in $98 \mathrm{ml}$ of glacial acetic acid to which $2 \mathrm{ml}$ of $\mathrm{H}_{2} \mathrm{SO}_{4}$ was then added), and the mixture was heated for $5 \mathrm{~min}$ in a boiling water bath. The sample was cooled, and absorbance was measured at $540 \mathrm{~nm}$ (Burton 1957, Montesinos 2007). All work was carried out under subdued light conditions. All experimental procedures were performed in triplets if the variation was less than $5 \%$ and the mean values ( \pm standard deviation) were determined.

To test the impact of the peptide on plant development, two types of one month old in vitro globe artichoke (Cynaracardunculus var. scolymus) cultures (young shoots and undifferentiated callus) were used as the source for treatments. It is well knowen that the globe artichoke callus and shoots are usually viable for only short period. So, we want to test the effect of only Cupep2 peptide on their viability. The callus was generated from global artichoke explants according to (Brutti 2000, Bekheet 2011). One piece of callus (approximately $400 \mathrm{mg}$ ) was placed in $4.5 \mathrm{~cm}$ glass petri dish containing medium. The cultures were grown on MS medium (Raaijmakers et al. 2006) 
supplemented with $3 \%$ sucrose $(\mathrm{w} / \mathrm{v})$ and $0.8 \%(\mathrm{w} / \mathrm{v})$ agar. The filter-sterilized Cupep-2 peptide was added to the autoclaved medium at concentrations of 0,25 , 50 and100 $\mathrm{nM}$. The $\mathrm{pH}$ of all the media was adjusted to 5.8. The cultures were incubated at $24 \pm 2^{\circ} \mathrm{C}$ and relative humidity of $50 \pm 5 \%$ under a $16 \mathrm{hrs}$ photoperiod regime with $30 \mu \mathrm{mol} \mathrm{m} \mathrm{m}^{-2} \mathrm{~S}^{-1}$ photosynthetic photon flux density provided by cool-white fluorescent light tube. These conditions were the same for both testing plant types.

\section{Results and Discussion}

Amino acid composition is a basic feature of protein sequence that defines a protein's secondary structure, folding type, subcellular location, and domain function. Here, we studied the potential functions of two peptides, Cupep-1 and 2 that were selected from the low molecular weight protein sequences of extracted proteins from the phloem sap of Chinese cucumber (Cucumus sativus L.) (Data not shown). It has been previously reported that most of the phloem sap proteins are involved in mediating developmental and defense responses such as redox reactions and proteases inhibition, (Kehr 2007, Kehr and Buhtz 2008). To predict a function of Cupep-1 and 2, we performed bioinformatics analyses of the two peptides. The isolated peptides Cupep-1 and 2 had a small molecular weight, 3.545, 3.507 KDa, respectively (Table 1). Both peptides have high SEQUEST ranking score, it may indicate tothat they have a trusted sequence, as long as the Delta $C N$ Correlation value $(\triangle \mathrm{CN}$ score) near to $\geq 0.2$ value (Table 1). The physico-chemical characterization analysis of Cupep-1 and Cupep-2 showed that the protein has 35 and 31 amino acids as unique peptides respectivily (Table 2 ). It contained proline $23 \%$, valine $17 \%$, serine $14 \%$, lysine $8.5 \%$ and $6 \%$ arginine (Fig. $1 \mathrm{~A}$ ).

The sequence homology search identified the Cupep-1 peptide as a defensin and saposin-like (Fig. 1A). This type of peptide can cross the cell membrane alone; therefore, it is called a cell penetrating peptide (Derossi et al. 1994). We found that Cupep-1 has a long half-life in mammalian, yeast and E. coli cells (100 $\mathrm{hrs},>20 \mathrm{hrs}$ and $>10 \mathrm{hrs}$, respectively). The long half-life is potentially beneficial for use in the treatment of asthma, inflammatory diseases, MS, or pulmonary hypertension (Table1). The sequence of Cupep-2 contained serine $20 \%$, arginine $13 \%$, glycine $9.5 \%$, threonine 9.5 and $6.5 \%$ valine (Fig. 1-B). It has low GRAVY 0.165 (Table 1). The low GRAVY value indicates a good possibility for interaction with water. Cumpep-2 shows $70 \%$ similarity to VIP2 protein via the sequence homology, which has a function in defensive cytotoxicity, pathogenicity, intracellular signaling, DNA repair and cell division (Han et al. 1999). This prediction would assign Cupep-2 multifunctional roles. The signature structure 
analysis predicted Cupep-2 to be a mitochondrial targeting peptide. Thus it can be potentially conjugated with peptides that act against human mitochondrial diseases as a clinical application (Table 2).

Table 1. The SEQUEST characterization data of Cupep-1 and 2.

\begin{tabular}{lllllll}
\hline Peptide & $\begin{array}{c}\text { MW } \\
(\mathrm{Da})\end{array}$ & $\begin{array}{c}\text { FDA } \\
(\geq)\end{array}$ & XCorr & $\mathrm{dCN}$ & $\begin{array}{l}\text { Trust } \\
\text { status }\end{array}$ & Annotation \\
\hline CuPep-1 & 3.55 & 0.1 & 3.570 & 0.213 & Excellent & $\begin{array}{l}\text { Aldo/keto reductase family } \\
\text { oxidoreductase soluble } \\
\text { NAD(P)(H) oxidoreductases } \\
\end{array}$ \\
& & & & & $\begin{array}{l}\text { whose chief purpose is to } \\
\text { reduce aldehydes and } \\
\text { ketones to primary and }\end{array}$ \\
& & & & & & $\begin{array}{l}\text { secondary alcohols } \\
\text { Retrotransposon protein, } \\
\text { CuPep-2 }\end{array}$ \\
& 3.51 & 0.1 & 3.422 & 0.142 & V. Good & \\
& & & & & $\begin{array}{l}\text { DNA integration, protein } \\
\text { transporter activity and } \\
\text { protein import into nucleus, } \\
\text { docking }\end{array}$ \\
\hline
\end{tabular}

FDR. The false discovery rate of a set of predictions is the expected percent of false predictions in the set of predictions. XCorr. The XCorr value is the cross-correlation value from the research. DelCn is the Delta Correlation value, which measures how different the first hit is from the second hit in the search results
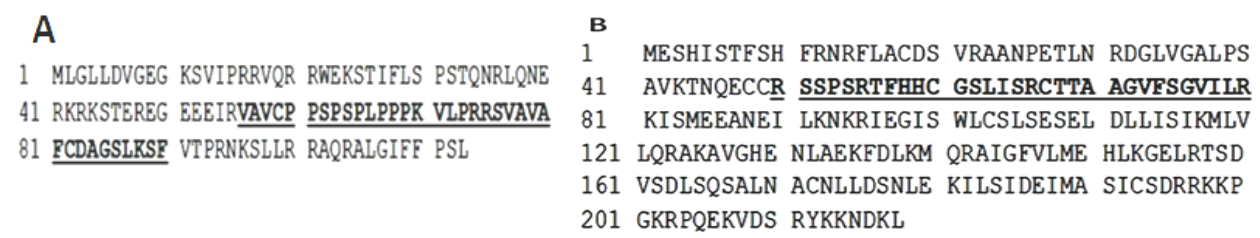

Fig. 1. The primary structure of Cupep-1 and Cupep-2 deduced from the proteome sequence of Cucumus sativus L. The amino acid sequence of protein precursors of Cupep-1 peptide (A) comprise of 113 amino acids. The cleaved peptide sequence of Cupep- 1 is 35 amino acids (bold and underlined) are located at the $\mathrm{N}$ terminal. (B) The primary structure of Cupep-2. The protein precursors of Cupep-2 peptide comprise of 216 amino acids. The cleaved peptide sequence of Cupep-2 are 31 amino acids (bold and underlined) are located at the $\mathrm{C}$ terminal

The Cupep-1 peptide exhibited strong antimicrobial activity against $B$. subtilis, E. coli, P. aeruginosa, St. aureus, S. cervisiae and C. albicans (Table 3). However, the peptide did not show any growth inhibitory effect on the fungi Aspregillus spp. (Table 3). The different growth inhibitory patterns on diverse types of microorganisms are likely to be related to differences in cell wall structures and protein synthesis of yeast, fungus and bacteria (Rauha et al. 2000). 
We observed a broad antimicrobial activity against E. coli, P. aeruginosa, St. aureus, $B$. subtilis and $C$. albicans were $16,15,15,15$, and $17 \mu \mathrm{g} / 100 \mathrm{ml}$ media. The variation in the effectiveness of Cupep-1 peptide against different strains may depend on the differences in the permeability of cell of those microbes (Dorman and Deans 2004, Ramadan and Asker 2012).

Table 2. The physico-chemical characterization of Cupep-1 and 2.

\begin{tabular}{lcclllll}
\hline \multirow{2}{*}{ Peptide } & $\begin{array}{c}\text { No. of } \\
\text { a.a }\end{array}$ & PI & $\begin{array}{l}\text { H.Life } \\
\text { H/Y/B }\end{array}$ & GRAVY & AMP & M/Ch-SP & SP \\
\hline CuPep-1 & 35 & 7.32 & $100 \mathrm{~h} / 20 \mathrm{~m} / 10 \mathrm{~m}$ & 0.403 & Yes & No & Yes \\
CuPep-2 & 31 & 5.91 & $1 \mathrm{~h} / 2 \mathrm{~m} / 2 \mathrm{~m}$ & 0.165 & might be & No & Yes \\
\hline
\end{tabular}

a.a: Amino acide. pI: Iosoelectric point. $\mathrm{H}$ life: Half life. H/Y/B: Human/yeast/pacteria peptide,. M/Ch-SP: Mitochondrial signal peptide or chloroplast signal peptide. SP: Signaling peptide.

Table 3. Antimicrobial activity of different concentrations of Cupep-1

\begin{tabular}{lccccccc}
\hline Sample $(\mu \mathrm{g})$ & \multicolumn{6}{c}{ Diameter of inhibition $(\mathrm{mm})$} \\
\cline { 2 - 8 } & & \multicolumn{6}{c}{ Bacteria } \\
\cline { 2 - 8 } & & B. subtilis & St. aureus & E. coli & P. aueginosa & S. cervisiae & C. albicans \\
\hline Peptide & 5 & $00.0 \pm 0.00$ & $00.0 \pm 0.00$ & $00.0 \pm 0.00$ & $00.0 \pm 0.00$ & $00.0 \pm 0.00$ & $00.0 \pm 0.00$ \\
& 10 & $00.0 \pm 0.00$ & $00.0 \pm 0.00$ & $00.0 \pm 0.00$ & $00.0 \pm 0.00$ & $00.0 \pm 0.00$ & $08.1 \pm 0.07$ \\
& 20 & $07.6 \pm 0.67$ & $08.3 \pm 0.88$ & $06.5 \pm 0.33$ & $07.3 \pm 0.07$ & $07.0 \pm 0.33$ & $10.3 \pm 0.33$ \\
& 30 & $11.5 \pm 0.88$ & $12.0 \pm 0.66$ & $08.7 \pm 0.66$ & $09.0 \pm 0.66$ & $09.5 \pm 0.66$ & $15.2 \pm 0.66$ \\
& 40 & $12.3 \pm 0.67$ & $14.3 \pm 0.88$ & $11.3 \pm 0.67$ & $12.0 \pm 0.88$ & $11.5 \pm 0.33$ & $18.0 \pm 0.33$ \\
& 50 & $15.0 \pm 0.88$ & $15.6 \pm 0.67$ & $14.0 \pm 0.88$ & $14.6 \pm 0.67$ & $14.0 \pm 0.67$ & $20.0 \pm 0.67$ \\
Tetracycline & 60 & $17.2 \pm 0.00$ & $18.1 \pm 0.00$ & $17.0 \pm 0.33$ & $16.4 \pm 0.66$ & $16.7 \pm 0.88$ & $22.5 \pm 0.88$ \\
Fluconazol & 10 & $24.0 \pm 0.30$ & $24.7 \pm 0.07$ & $25.0 \pm 0.09$ & $26.0 \pm 0.06$ & $00.0 \pm 0.00$ & $00.0 \pm 0.00$ \\
\hline
\end{tabular}

Each value represents mean of sample \pm Sd for $n=3$ discks. Diameter of inhibition zone was measured as the clear area centered on the agar well containing the sample, well with non-inhibition zone were recorded. Measurements were taken after $24 \mathrm{hrs}$ incubation with yeast, $24-48 \mathrm{hrs}$ with bacteria.

It was found that the peptide Cupep-1 had a drastic negative effect on the biosynthesis of total protein and total lipids in cells of B. subtilis (Figs 3, 4). This effect positively correlated with increasing the Cupep-1 concentrations and incubation period. On the other hand, the peptide had only a slight impact on the biosynthesis of acid soluble phosphorus (Fig. 5) 


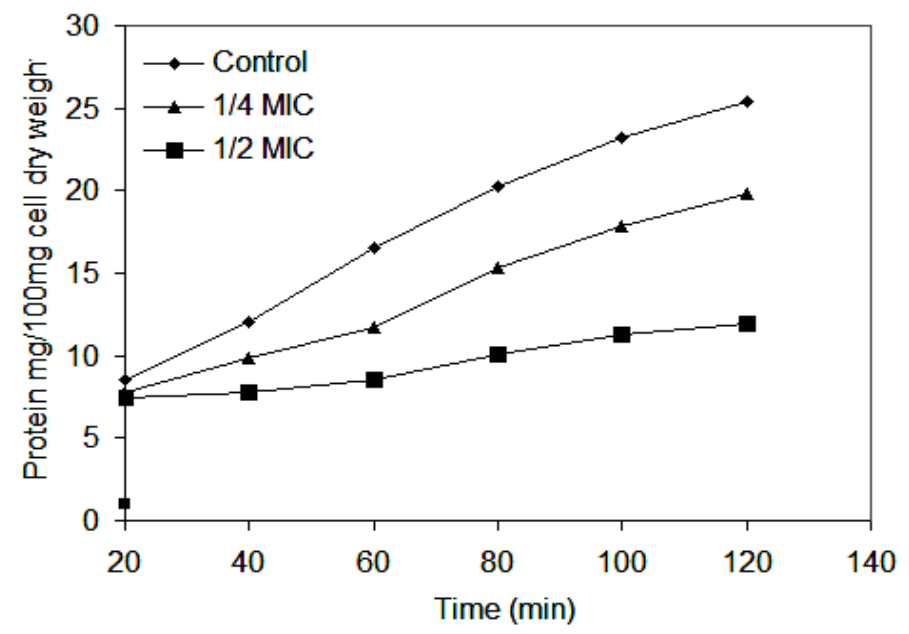

Fig. 3. Effect of Cupep-1 peptide on total protein content of B. subtilis NRRL B-94.

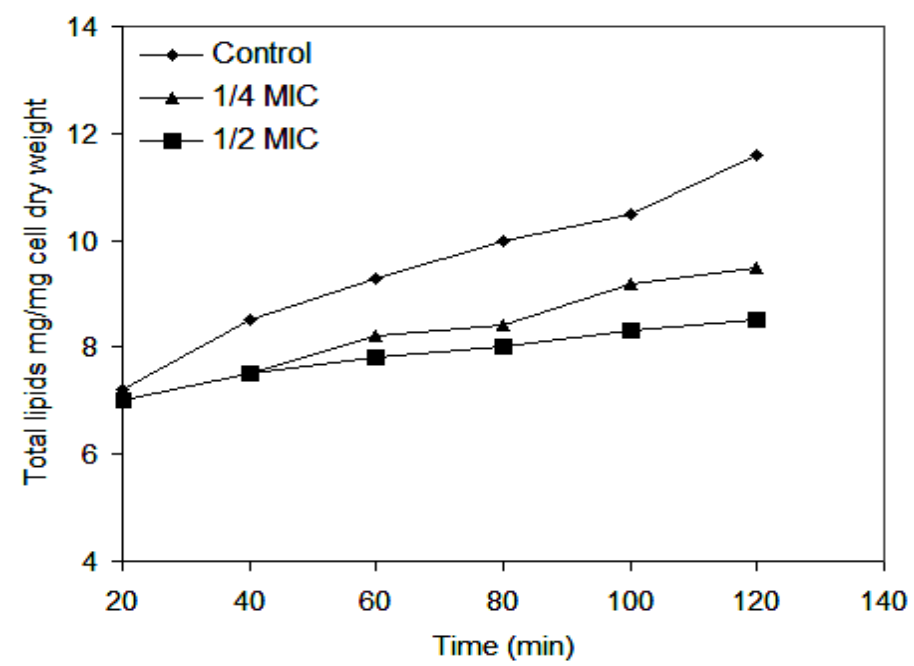

Fig. 4. Effect of Cupep-1 peptide on total lipid contents of B. subtilis NRRL B-94.

However, the peptide showed negative effects on total nucleic acids (RNA and DNA) in the cells of B. subtilis (Figs 6, 7). The effect of Cupep-1 resembles the action of some chemotherapeutic agents such as Mj-AMP1 and Mj-AMPS drived from purple jasmine (Cammue et al. 1992) that influence the biosynthesis of nucleic acids, or bind to nucleic acids to hinder transcription or translation. The majorities of these drugs are unselective and affects animal and bacterial cells alike, thereby their use is being limited (Ramadan and Asker 2012, Shuichi et al. 2000). It will be interesting to test the effect of Cupep-1 on animal cells to predict whether it can be used in human therapy. 


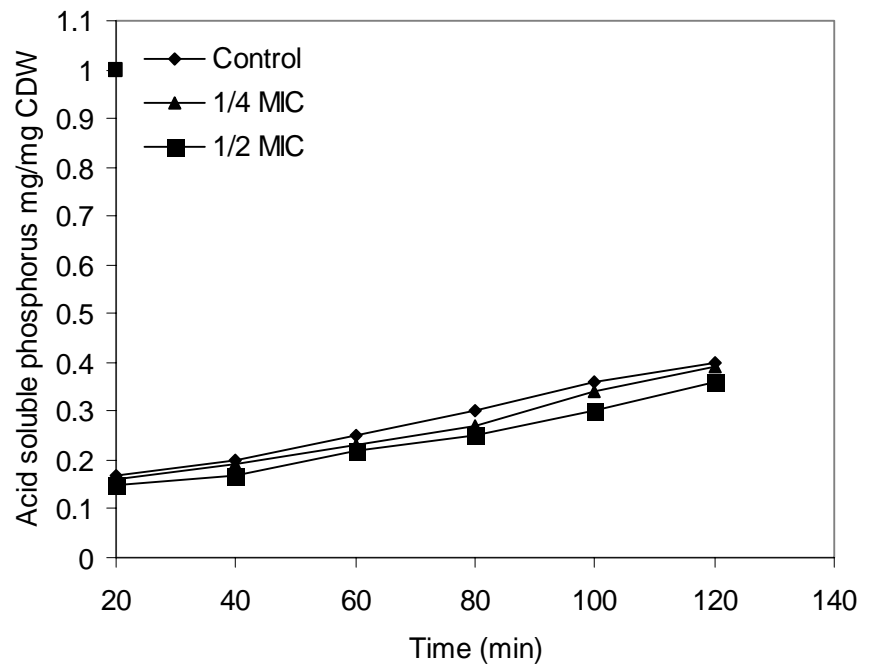

Fig. 5. Effect of Cupep-1 peptide on acid soluble phosphorus content of B. subtilis NRRL B-94.

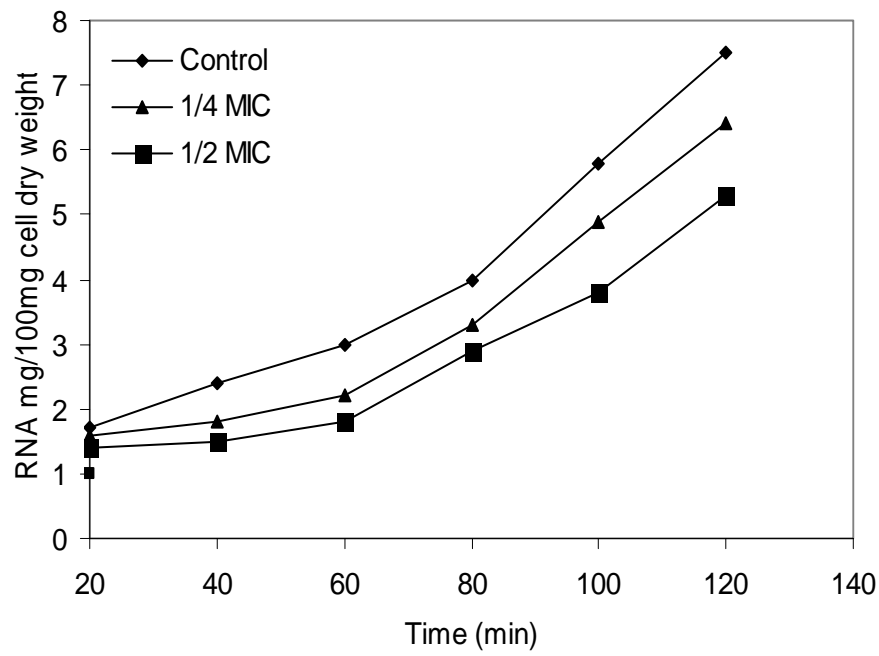

Fig. 6. Effect of Cupep-1 peptide on RNA content of B. subtilis NRRL B-94.

To examine the predicted function of Cupep-2 in plant signaling, a 4-weekold callus culture and propagated shoots were used to test the effect of Cupep-2 on globe artichoke plant cell development and long viability as is was found to have a short vible beriod (Shawky and Aly 2007). Four concentrations of synthetic Cupep-2 (25, 50 and $100 \mathrm{nM}$ ) were used to investigate the active concentration of the tested peptides in plant cell development. In the control 
treatment, the excised shoots grow well for 4 weeks then started to senesce and finally died by two month (Fig. 8A). The shoots grown on 25 and100 $\mathrm{nM}$ did not show any difference in comparison to the control shoots (Fig. 8A). In contrast, shoots grown on medium containing $50 \mathrm{nM}$ of cupep-2 stayed green and did not show signs of senescence for up to two months (Fig. 8A). Interestingly, the shoots grown on $50 \mathrm{nM}$ cupep-2 caused activation and initiation of terminal buds after six weeks of culture (Fig. 8B, C).

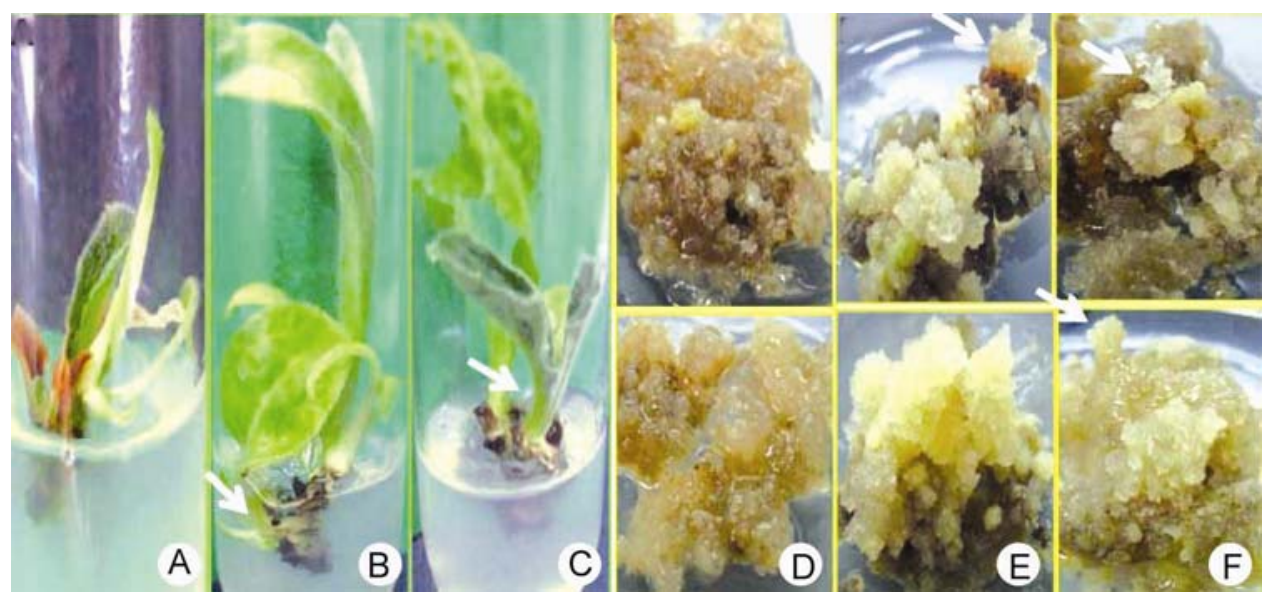

Fig. 6. Effect of different concentrations of the Cupep-2 peptide in shoot- and callus culture of globe artichoke (Cynaracardunculus var. scolymus) after two months of growth. (A) Control shoot without peptide, (B, C) shoots growing in the medium supplemented with $50 \mathrm{nM}$ Cupep-2, (D) control callus, (E and F) callus growing in the media supplemented with 25 and $100 \mathrm{nM}$ Cupep-2.

We further tested the impact of Cupep-2 on undifferentiated cells, callus of the global artichoke. Calli were grown for two months on callus maintenance medium. At the end of the experiment, calli of the control treatment turned to brown color (Fig. 8D). Calli grown in the medium supplemented with $50 \mathrm{nM}$ Cupep-2 did not trigger any development changes in undifferentiated cells and did not show a difference from the control (Fig. 8D). In contrast, the Cupep-2 concentrations 25 and $100 \mathrm{nM}$ induced healthy creamy calli growth (Fig. 8E). In addition, the concentration $100 \mathrm{nM}$ favored organogenesis leading to the development of somatic embryos (Fig. 8E). None of the concentrations showed inhibitory callus growth.

The global artichoke cultures responded to the Cupep- 2 peptide in a concentration and developmental stage dependent manners. They promoted organogenesis or shoot development. These results would assign Cupep-2 a signaling role in plant development. The Cupep-2 seems to play a similar role of 
cytokinins in plants. It is well known that cytokinins stimulate plant cell division and participate in the induction of adventitious bud formation (Gaspar et al. 1996, Gaspar et al. 2003). Plantgrowth homones are thought to be involved in differentiation and further development of the morphogenetic event (Becraft 1998), which is similar to what we have observed after the application of Cupep-2.

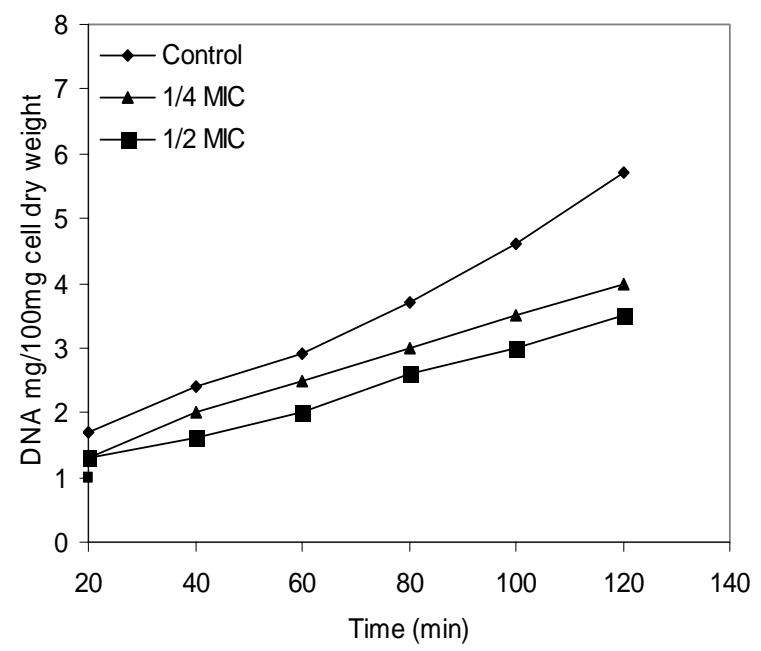

Fig. 7. Effect of Cupep-1 peptide on DNA content of B. subtilis NRRL B-94.

There is an increasing attention to and research on the role of small peptides in plant defence and development. It is evidently clear that is the understanding and recognition of the exogenous pepties signals pathways was inducted from the plant indigenous cellular signals component system. In this paper we try to examen the actual biological activities and confirmed the predicted function through analysis of two synthetic peptides, Cupep-1 and Cupep-2, isolated which were extracted and sequenced from Chinese Long cucumber phloem sap. The Cupep-1 peptide has shown promising antimicrobial activity against bacteria and yeast by affecting protein biosynthesis. This property would render Cupep-1a potential natural food preservative to inhibit microbial growth. The peptide Cupep-2 showed a potential role in plant development. The effect of Cupep-2 on cell or organ differentiation was dependent on the concentration and the developmental stage of the treated cells or tissue. Obviously, we are just beginning to unravel the actual biological function of these two peptides in the phloem sap of Chinese cucumber. More experiments are needed to identify a new regulatory signaling peptide of plant defense, growth promotion and development that lead to new discoveries in signal perception and cellular responses. 


\section{Acknowledgement}

This work was supported by the National Research Center (NRC) of Egypt (in house project No. 91102) and the Chinese Academy of Science for peptides sequence and analysis.

\section{References}

Allahghadri T, Rasooli I, Owlia P, Nadooshan MJ, Ghazanfari T, Taghizadeh M and Astaneh SD (2010) Antimicrobial property, antioxidant capacity, and cytotoxicity of essential oil from cumin produced in Iran. J. Food Sci. 75: 54-61.

Baker DA (2000) Vascular transport of auxins and cytokinins in Ricinus. Plant Growth Regulators 32: 157-160.

Becraft PW (1998) Receptor kinases in plant development. Trends in Plant Sci. 3:384-388.

Bekheet SA (2011) In vitro biomass production of liver-protective compounds from Globe artichoke (Cynara scolymus L.) and Milk thistle (Silybum marianum) plants. Emirates J. Food and Agril. 23: 473-481.

Bligh EG and Dyer WJ (1959) A rapid method for total lipid extraction and purification. Can. J. Biochem. Phys. 37: 911-917.

Bradford MM (1976) A rapid and sensitive method for the quotation of microgram quantities of protein utilizing the principle of protein-day binding. Anal. Biochem. 72: 248-254.

Brutti C, Apostolo NM, Ferrarotti SA, Llorente BE and Krymkiewicz N (2000) Micropropagation of Cynara scolymus L. employing cyclodextrins to promote rhizogenesis. Scientia Horticul. 83: 1-10.

Burton K (1957) A study of the conditions and mechanism of diphenylamine reaction for colorimetric estimation of deoxyribonucleic acid. J. Biochem. 62: 315-323.

Cammue BP, De Bolle MF, Terras FR, Proost P,Damme J V, Rees SB, Vanderleyden J, and Broekaert WF (1992) Haracterization of a Novel Class of Plant Antimicrobial Peptides from Mirabilis jalapa L. Seeds. J. Biol. Chem. 267(4): 2228-2233.

Chen PS, Toribara TY and Warner H (1956) Microdetermination of Phosphous. Anal. Biochem. 28: 1756-1758.

Derossi D, Joliot AH, Chassaing H and Prochiantz A (1994) The third helix of the Antennapedia homeodomain translocates through biological membranes. J. Biol. Chem. 269: 10444-10450.

Dorman DH and Deans GS (2004) Chemical composition antimicrobial and in vitro antioxidant-properties of Monarda citriodora var. citriodora, Myristica fragrans, Origanum vulgare ssp., Hirtum pelargonium sp. and Thymus zygisoils. J. Essent. Oil Res. 16: $145-150$.

Garnier J, Osguthorpe DJ and Robson B (1978) Analysis of the accuracy and implications of simple methods for predicting the secondary structure of globular proteins. J. Mol. Biol. 120: 97-120. 
Gaspar T, Kevers C, Penel C, Greppin H, Reid DM and Thorpe TA (1996) Plant hormones and plant growth regulators in plant tissue culture. In Vitro Cell Dev. Biol. Plant 32: 272-289.

Gaspar T, Kevers C, Faivre-Rampant O, Crevecoeur M, Penel CL, Greppin H and Dommes J (2003) Changing concepts in plant hormone action. In Vitro Cell Dev. Biol. Plant 39: 85-106.

Greenwood D (1983) Antimicrobial chemotherapy, Part II. In Laboratory Aspects of Antimicrobial Therapy. (D. Greenwood, Ed.). p. 71, Bailliere, Tindall, London.

Han S, Craig J A, Putnam CD, Carozzi NB and Tainer JA (1999) Evolution and mechanism from structures of an ADP-ribosylating toxin and NAD complex. Nat. Struc. Molec. Biol. 6: 932-936.

Hogeboom GH and Schneider WC (1950) Cytochemical studies of mammalian tissues: iii. Isocitric dehydrogenase and triphosphopyridine nucleotide-cytochromec reductase of mouse liver. J. Biol. Chem. 186: 417-427.

Hopp TP and Woods KR (1981) Prediction of protein antigenic determinants from amino acid sequences. PNAS 78:3824-3828.

Jameson BA and Wolf H (1988) The antigenic index: a novel algorithm for predicting antigenic determinants. Computer Appl. Biosci. 4: 181-186.

Jorgensen RA (2002) RNA traffics information systemically in plants. PNAS 99: 1156111563.

Kehr J (2006) Phloem sap proteins: their identities and potential roles in the interaction between plants and phloem-feeding insects. J. Exp. Bot. 57: 767-774.

Kehr J (2007) Protein extraction from the xylem and phloem sap. Methods in Mol. Biol. 3: 27-35.

Kehr J (2008) Buhtz A. Long distance transport and movement of RNA through the phloem. J. Exp. Bot. 59: 85-92.

Kende H and Zeevaart JAD (1997) The five "classical" plant hormones. Plant Cell 9:11971210.

Knight JA, Anderson S and James MR (1972) Chemical basis of the sulfo-phosphovanillin reaction for estimating total serum lipids. Clinical Chem. 18: 199-202.

Lough TJ and Lucas WJ (2006) Integrative Plant Biology: Role of Phloem Long-Distance Macromolecular Trafficking. Annu. Rev. Plant Biol. 57: 203-32.

Lucas WJ, Yoo BC and Kragler F (2001) RNA as a long-distance information macromolecule in plants. Nature Rev. ef Mol. Cell Biol. 2: 849-857.

Malik CP and Singh MB (1980) Enzymology and Histo-Enzymology: A Text Manual. Kalyani Publishers, pp. 286. New Delhi.

Montesinos E (2007) Antimicrobial peptides and plant disease control. FEMS Microbiology Letters 270: 1-11.

NCCLS (1990) Methods for Dilution Antimicrobial Susceptibility Tests for Bacteria that Grow Aerobically, 2nd Ed., Approved standard NCCLS Document M7-A2, NCCLS, Villanova, PA. 
Raaijmakers JM, deBruijn I and deKock MJD (2006) Cyclic lipopeptide production by plant-associated Pseudomonas ssp. diversity, activity, biosynthesis, and regulation. Mol. Plant Microbe Interaction 19: 699-710.

Ramadan M F, Asker MS and Tadros M (2012) Antiradical and antimicrobial properties of cold-pressed black cumin and cumin oils. Eur. Food Res. Tech. 234:833-844.

Ramadan MF and Asker MS (2009) Antimicrobial and antiviral impact of novel quercetin-enriched lecithin. J. Food Biochem. 33: 557-571.

Rauha JP, Remes S, Heinonen M, Hopia A, Kahkonen M, Kujala T, Pihlaja K, Vuorela H and Vuorela P (2000) Antimicrobial effects of Finnish plant extracts containing flavonoids and other phenolic compound. Int. J. Food Microbial. 56: 3-12.

Ruiz-Medrano R, Xoconostle-Cazares B and Lucas WJ (2001) The phloem as a conduit for inter-organ communication. Curr. Opin. Plant Biol. 4: 202-209.

Schaller A (2001) Bioactive Peptides as Signal Molecules in Plant Defense, Growth, and Development. Atta-ur-Rahman (Ed.) Studies in Natural Products Chemistry, Vol. 25.

Shawky B and Aly UI (2007) In vitro Conservation of Globe Artichoke (Cynara scolymus L.) Germplasm. Int. J. Agri. Biol. 9(3): 404-407.

Shuichi A, Hidenori N, Sumito I, Hiroaki T, Hiroshi S, Shuichi K, Naofumi M, Kouji M and Hitonobu T (2000) Interleukin-8 gene repression by clarithormyecin is mediated by the activator protein-1 binding site in human bronchial epithelial cells. Am J Respir Cell Mol Biol. 22: 51-60.

Skoog F and Miller CO (1957) Chemical regulation of growth and organ formation in plant tissue cultures in vitro. Symp. Soc. Exper. Biol. 11: 118-131.

Stewart JM and Young JD (1984) Solid phase peptide synthesis. 2nd ed. Rockford, Illinois; Pierce Chemical Company; p. 176. ISBN 0-935940-03-0.

Tsuchiya H, Sato M, Miyazaki T, Fujiwara S, Tanigaki S, Ohyama M, Tanaka T and Iinuma M (1996) Comparative study on the antibacterial activity of phytochemical flavanones against methicillin resistant Staphylococcus aureus. J. Ethnopharmacol. 50: 27-34.

Walz C, Giavalisco P, Schad M, Juenger M, Klose J and Kehr J (2004) Proteomics of cucurbit phloem exudate reveals a network of defense proteins. Phytochem. 65: 17951804.

Zimmermann $\mathbf{M H}$ and Ziegler $\mathbf{H}$ (1975) Transport in plants: phloem transport. In: Encyclopedia of plant physiology Vol. 1. New York: Springer. 480-503. 